\title{
ORAL TRANSMISSION OF CHAGAS DISEASE: IMPORTANCE OF Trypanosoma cruzi BIODEME IN THE INTRAGASTRIC EXPERIMENTAL INFECTION
}

Edson Luiz P. CAMANDAROBA, Clarissa M. PINHEIRO LIMA \& Sonia G. ANDRADE

\begin{abstract}
SUMMARY
Oral transmission of Trypanosoma cruzi has been suspected when epidemic episodes of acute infection were observed in areas devoid of domiciled insect vectors. Considering that the distribution of $T$. cruzi biodemes differs in sylvatic and domestic cycles, results of studies on biodemes can be of interest regarding oral transmission. The infectivity of $T$. cruzi strains of different biodemes was tested in mice subjected to infection by the digestive route (gavage). Swiss mice were infected either with the Peruvian strain (Biodeme Type I, Z2b) or the Colombian strain (Biodeme Type III, Z1, or T. cruzi I); for control, intraperitoneal inoculation was performed in a group of mice. The Colombian strain revealed a similar high infectivity and pathogenicity when either route of infection was used. However, the Peruvian strain showed contrasting levels of infectivity and pathogenicity, being high by intraperitoneal inoculation and low when the gastric route was used. The higher infectivity of the Colombian strain (Biodeme Type III) by gastric inoculation is in keeping with its role in the epidemic episodes of acute Chagas disease registered in the literature, since strains belonging to Biodeme III are most often found in sylvatic hosts.
\end{abstract}

KEYWORDS: Trypanosoma cruzi; Oral transmission; Experimental intragastric infection; T.cruzi strains infectivity; Biodemes.

\section{INTRODUCTION}

Although the vectorial transmission of Chagas disease by the domiciliated vector (Triatoma infestans), has been successfully controlled in Brazil, other ways of contamination can be responsible for new cases of infection with $T$. cruzi, as for example, by the digestive route. The contamination of foods by sylvatic vectors and vertebrate reservoirs of Trypanosoma cruzi is probably an important factor for the digestive transmission of Chagas disease. Epidemic episodes of human disease, that has been attributed to the oral infection have been registered in Teutonia - RS ${ }^{10,11}$, and Catolé do Rocha - $\mathrm{PB}^{14}$. More recently, several episodes have been identified in the Brazilian Amazonia ${ }^{5,15,16,17}$.

The factors responsible for the high infectivity of the ingested parasites are not well known. The occurrence of severe cases of infection, leading to death of a percentage of infected individuals ${ }^{11,12,14}$, indicates a high pathogenicity of the parasites and its capacity to penetrate through the gastric mucosa, even after passing through the gastric acid contents. The influence of the parasite strain during oral transmission, has not been previously considered but it probably is an important one. In the sylvatic hosts there is a predominance of Zymodeme 1 of T. cruzi ${ }^{4,9}$ which corresponds to the Biodeme Type $\mathrm{III}^{3}$. The occurrence of $\mathrm{Z1}$ strains in the sylvatic reservoirs has been confirmed by ZINGALES et al. ${ }^{18}$ by ribosomal characterization, resulting in their inclusion into the $T$. cruzi I group $^{13}$. This suggests the possible involvement of the Type III, Z1 strains in the epidemic episodes of oral transmission registered in the literature. The study of three strains sent to us by S.A. Valente, isolated from infected patients from one epidemic episode in Icoaraci - Pará ${ }^{5}$ revealed the Biodeme Type III, Z1 ( Pará strains) ${ }^{3}$; the same happened with five strains from Catolé do Rocha - $\mathrm{PB}^{14}$ that have been given to us by C. M. Brizola and also characterized as Type III, Z1 (Paraiba strains) ${ }^{3}$.These are indirect evidences of the involvement of sylvatic strains in the described epidemic episodes.

In the present study we intend to experimentally investigate the influence of the biodemes of $T$. cruzi in the digestive transmission of Chagas disease, taking into account the infectivity and pathogenicity revealed by different strains, during intragastric infection. With this objective, the Peruvian strain, biodeme type I and the Colombian strain, biodeme Type III were used. Both strains produce intense lesions in the experimental animal when applied by the intraperitoneal route. It is interesting to investigate their pathogenicity, after the intragastric inoculation, by evaluating the evolution of infection as well as tissue lesions and parasite burden in different organs, in comparison with the intraperitoneal route.

\section{MATERIAL AND METHODS}

Experimental animals - Outbred Swiss mice weighing from 15 to $20 \mathrm{~g}$, reared in the Centro de Pesquisas Gonçalo Moniz, were used in the

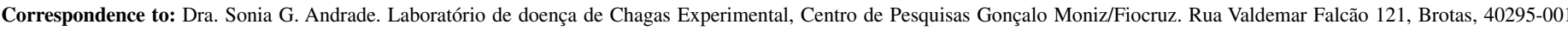
Salvador, Bahia, Brasil. Fone/Fax +071-356-8790. E-mail: sgandrade@ cpqgm.fiocruz.br 


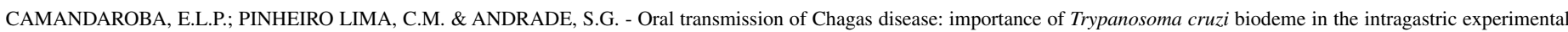
infection. Rev. Inst. Med. trop. S. Paulo, 44(2):97-103, 2002.

present investigation. The maintenance of the experimental animals complies with the guide lines for the human use of laboratory animals.

Experimental groups -The mice were divided into two main groups:

Group I - 75 mice infected with the Colombian strain (Type III, Z1, T. cruzi I). This group was divided into two subgroups:

Ia - 25 mice infected by intraperitoneal (IP) route.

$I b-50$ mice infected by intragastric (IG) route.

Normal controls - 15 uninfected mice in which IG administration of PBS has been performed.

Group II - 40 mice infected with the Peruvian strain (Biodeme Type I, Z2b). This group was divided into two subgroups:

II -18 mice infected by IP route.

$I I b-22$ mice infected by IG route.

Normal controls - 10 uninfected mice, receiving IG administration of PBS.

Inocula - Trypomastigote forms were obtained from the blood of infected mice; after centrifugation at $1,500 \mathrm{~g}$ for separation of blood elements, the supernatant was washed with PBS, pH 7.3 and centrifugation at 4,500 g; the pellet was suspended in PBS pH 7.3 and trypomastigotes were counted in a Neubauer chamber. The inoculum was adjusted to $5 \times 10^{4}$ trypomastigotes in $0.2 \mathrm{ml}$.

For IG inoculation, the mice were maintained starved for 12 hours. Infection was performed by gavage, with a special needle (Biomedical Needles, Popper \& Sons, Inc.), being injected into the stomach $1.0 \mathrm{ml}$ of a suspension containing $0.2 \mathrm{ml}$ of the inoculum diluted in $0.8 \mathrm{ml}$ of PBS, $\mathrm{pH}$ 7.3. Uninfected controls received $1.0 \mathrm{ml}$ of PBS by IG inoculation. The IP inoculation was performed with $0.2 \mathrm{ml}$ of the inoculum.

Parasitemia - The media of the number of trypomastigotes counted in the peripheral blood of 5 animals, in 50 microscopic fields of $400 \mathrm{X}$ represented the daily parasitemia.

\section{Parasitemia- Peruvian strain}
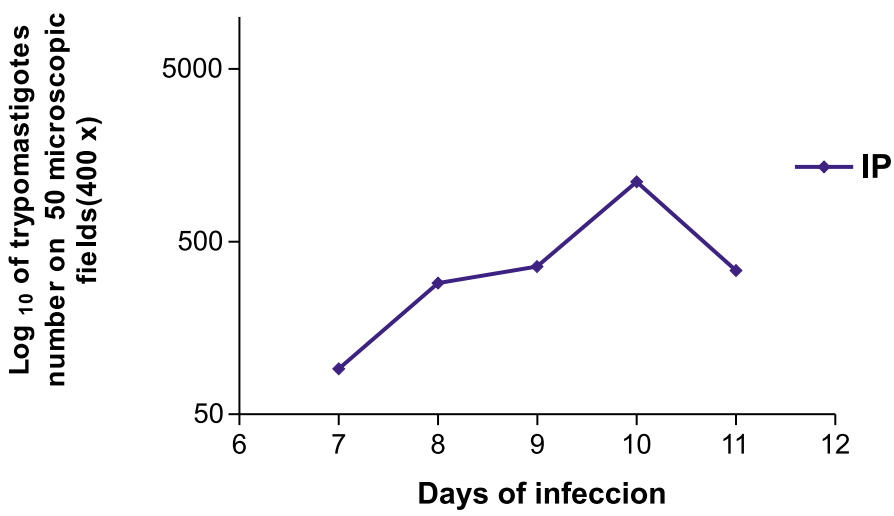

Fig. 1 - Parasitemic levels in mice infected by intraperitoneal route with the Peruvian strain of $T$. cruzi.
Histopathological study - The animals infected with the Peruvian strain were sacrificed at the $7,8,9,10,12$ days post-inoculation, three animals in each point.

The mice infected with the Colombian strain were sacrificed in the $15^{\text {th }}, 20^{\text {th }}, 25^{\text {th }}$ and $30^{\text {th }}$ day post-infection.

Sections of the heart, skeletal muscle, liver and spleen as well as sections of the stomach, esophagus, peri-esophageal and peri-cardiac mediastinal loose connective tissue, were fixed in $10 \%$ Formalin and paraffin embedded. Sections $5 \mu \mathrm{m}$ thick, were stained with Hematoxylin and Eosin for histopathological study.

\section{RESULTS}

\section{I - Infection with the Peruvian strain}

Parasitemia - In mice infected by IP route, parasitemia attained the peak at the $10^{\text {th }}$ day of infection (Fig. 1), and decreased rapidly as expected to Biodeme Type I. In mice infected by IG route the parasitemia persisted subpatent until the $9^{\text {th }}$ and $10^{\text {th }}$ day of infection when it became positive at very low levels, followed by negativation (data not shown).

Mortality - In the group infected by IP route a $100 \%$ mortality occurred until the $14^{\text {th }}$ day post-infection. In mice infected by IG route mortality was of $20 \%$ until the $21^{\text {st }}$ day of infection.

\section{Histopathological study}

Infection with the Peruvian strain given by the intraperitoneal route (Table 1) - An intense and early involvement of the spleen and liver with evident macrophagotropism was seen from the $7^{\text {th }}$ to the $9^{\text {th }}$ day post infection. An intense hyperplasia of the germinal centers of lymphoid follicles of the spleen was present, with vacuolated macrophages containing intracellular parasites (Fig. 3A). The liver showed mononuclear infiltrates in the parenchyma and the presence of amastigotes in Kupffer cells. By the $10^{\text {th }}$ and $11^{\text {th }}$ days post-infection the myocardium and skeletal muscle presented moderate to intense

\section{Parasitemia - Colombian strain}

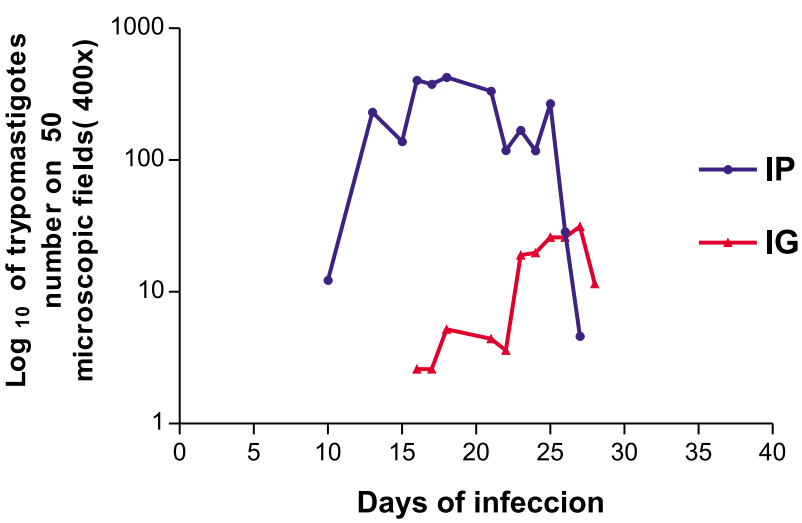

Fig. 2 - Parasitemic levels in mice infected with the Colombian strain of T. cruzi by the intraperitoneal (IP) route and by the intragastric (IG) route. 


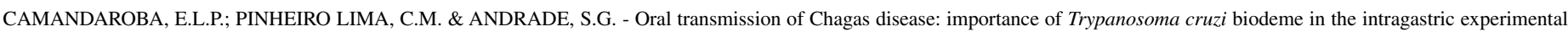
infection. Rev. Inst. Med. trop. S. Paulo, 44(2):97-103, 2002.

inflammatory infiltration, necrosis of cardiac and skeletal myocells and the presence of intracellular amastigotes (Fig. 3-B,C). Sections of the esophagus and stomach showed normal structure, without parasites (Fig. 3-D). Amastigotes nests were rarely seen within the muscle layer of these organs. The periesophagic and pericardiac mediastinal loose connective tissue showed diffuse mononuclear infiltrate and the presence of amastigotes in the cytoplasm of adipocytes and macrophages.

Infection with the Peruvian strain given by intragastric route (Table 2) - From the $7^{\text {th }}$ to the $10^{\text {th }}$ day of infection the tissue alterations were limited to a mild to moderate hyperplasia of the lymphoid follicles of the spleen with the presence of vacuolated macrophages containing cells debris (Fig. 3-E) and the presence of scarce parasites at the $11^{\text {th }}$ day. Focal mononuclear infiltrates were seen in the liver parenchyma. The myocardium showed mild focal mononuclear infiltrates that increased by the $11^{\text {th }}$ day, in the absence of parasites (Fig. 3-F). A mild to moderate interstitial infiltrate was seen in skeletal muscle, without parasites (Fig. 3-G). In sections of the esophagus and stomach a diffuse mononuclear infiltration of the mucosal and submucosal layers was seen, without parasites (Fig. 3-H).

Normal controls - Sections of the several organs did not show histopathological alterations.

\section{II - Infection with the Colombian strain}

Parasitemia - Fig. 2 shows the evolution of the parasitemia in the mice infected by IP and by IG routes. In both groups parasitemia increased progressively from the $10^{\text {th }}$ day of infection, with maximal peak between the $20^{\text {th }}$ and $30^{\text {th }}$ days. Significant differences were observed between the higher levels attained in those infected by IP route as compared with the IG route.

Mortality rates - It was of $10 \%$ until the $30^{\text {th }}$ day of infection in the mice infected by IP route and of $0 \%$ in the infected by IG route.

\section{Histopathological study}

Infection with the Colombian strain given by the intraperitoneal route (Table 3) - Inflammatory lesions and parasitism were predominant in skeletal muscle and myocardium. The alterations became evident by the $14^{\text {th }}$ day and turned most intense in 20 to 25 days post-infection, showing intense focal inflammatory infiltrates in the myocardium, corresponding to necrosis of parasitized myocells and diffuse interstitial mononuclear infiltration (Fig. 4A). Skeletal muscles presented intense inflammatory lesions, with focal destruction of parasitized fibers (Fig. 4-B,C). The spleen showed mild hyperplasia of the lymphoid follicles and the liver presented scarce mononuclear infiltrates in the parenchyma in the absence of parasites. The study of the mucosal and submucosal layers of esophagus and stomach, showed normal aspects in most cases, and rarely a mild mononuclear infiltrate was seen (Fig. 4-D). The muscle layer of the stomach and esophagus, occasionally showed the presence of intracellular amastigotes, without inflammatory reaction. The pericardiac and periesophagic mediastinal loose connective tissue did not show inflammatory lesions, nor the presence of parasites.

Infection with the Colombian strain given by intragastric route (Table 4) - Inflammatory lesions of the myocardium and skeletal muscles were absent by the $14^{\text {th }}$ day of infection and became evident and intense from the $20^{\text {th }}$ day on. In the myocardium, the presence of intracellular amastigotes was frequent, with necrosis of parasitized cells and focal mononuclear infiltrates. Diffuse moderate to intense interstitial infiltration was also seen (Fig. 4-E, F). Skeletal muscle sections showed moderate to intense parasitism with necrosis of parasitized myocells, focal and diffuse inflammatory infiltration (Fig. 4-G). The spleen showed mild hyperplasia of lymphoid follicles and mild mononuclear infiltrates in the hepatic parenchyma, without parasites. Sections of the esophagus and stomach revealed in all cases the presence of moderate to intense mononuclear infiltration of the mucosal and submucosal layers, without parasites (Fig. 4-H).

Normal controls - The several examined organs did not show histopathological alterations.

\section{DISCUSSION}

The possibility of oral transmission of $T$. cruzi infection has been confirmed by different authors ${ }^{1,7,8}$, however little is known about the role of the strain of the parasite. Results of the present study have indicated a clear difference in infectivity of two different strains of $T$. cruzi, when inoculated by the intragastric route. These strains are highly pathogenic for mice and this has been confirmed in the present paper when the animals were infected by the intraperitoneal route. However the direct intragastric instillation of the parasites suspension in PBS, into direct contact with the gastric juice, has clearly influenced the infectivity of the parasites. The Peruvian strain, highly virulent when injected intraperitoneally, produces in mice high levels of parasitemia and intense macrophagotropism; this same strain determined very low levels of parasitemia by intragastric infection, with low parasitism of macrophages and mild to moderate tissue lesions. The Colombian strain, on the contrary, determined intense myotropism, with involvement of myocardium and skeletal muscle in mice infected by intragastric route, being the tissue lesions comparable to those seen in mice infected by the intraperitoneal route, although with a delay in the evolution and lower levels of parasitemia. The presence of parasites into the gastric or esophageal mucosa, necessary to confirm its invasion by $T$. cruzi, has not been detected. However the presence of significant inflammatory mononuclear infiltrate, more evident in the gastric-esophageal transition, may represent an evidence of invasion. HOFT et $a l^{7}$ infected mice by oral route and shown the presence of parasites and mononuclear infiltrates within the gastric mucosa; the cellular infiltration was attributed to the immune response of the mucosa, stimulated by the presence of $T$. cruzi $i^{7}$.

The present findings are in accordance with the clinicoepidemiological observations that considered the familial epidemic episodes in the Amazonic regions resulting from the ingestion of food contaminated with the excreta of sylvatic vertebrates and vectors, as reviewed by VALENTE et $a l .{ }^{15}$. These findings suggest that strains more adapted to the sylvatic cycle are involved in these episodes. This is most probable considering that the marsupials lodge $T$. cruzi in its evolutive stages, into the anal glands, and thus could spontaneously eliminate them to the exterior ${ }^{6}$. These clinico-epidemiological observations, match well with the findings of the present study, that shows the maintenance of the pathogenicity of the Colombian strain (prototype of biodeme Type III) by intragastric infection, as compared with the Peruvian strain (Biodeme Type I). This indicate that the digestive infection could be considered as an important way of transmission of $T$. cruzi, in the geographical regions 


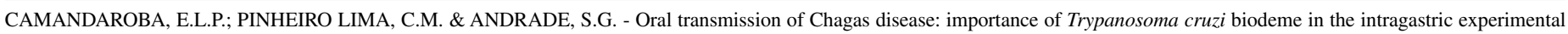
infection. Rev. Inst. Med. trop. S. Paulo, 44(2):97-103, 2002.

Table 1

Degree of histopathological lesions and parasitism in mice infected with the Peruvian strain of T. cruzi by intraperitoneal route

\begin{tabular}{|c|c|c|c|c|c|c|c|c|}
\hline \multirow{2}{*}{$\begin{array}{l}\text { Days of } \\
\text { infection }\end{array}$} & \multicolumn{2}{|c|}{ Spleen } & \multicolumn{2}{|c|}{ Liver } & \multicolumn{2}{|c|}{ Myocardium } & \multicolumn{2}{|c|}{ Skeletal Muscle } \\
\hline & LyFH* & Paras* & Infl. Infilt* & Paras* & Infl. Infilt* & Paras* & Infl. Infilt* & Paras* \\
\hline $7^{\text {th }}$ & + & -- & + & -- & -- & -- & -- & -- \\
\hline $9^{\text {th }}$ & ++ & $+/++$ & $+/++$ & $+/++$ & + & + & -- & -- \\
\hline $10^{\text {th }}$ & $++/+++$ & $++/+++$ & ++ & $+/++$ & $++/+++$ & $+/++$ & $+/++$ & $+/++$ \\
\hline $11^{\text {th }}$ & $++/+++$ & $++/+++$ & ++ & $++/+++$ & $++/+++$ & $++/+++$ & $+/+++$ & $+/+++$ \\
\hline
\end{tabular}

LyFH = Lymphoid follicles hyperplasia; Paras = Parasitism; Infl. Infilt = Inflammatory infiltration; (--) negative; (+) mild degree; (++) moderate degree; +++ intense degree; * from / to

Table 2

Degree of histopathological lesions and parasitism in mice infected with the Peruvian strain of $T$. cruzi by intragastric route

\begin{tabular}{|c|c|c|c|c|c|c|c|c|}
\hline \multirow{2}{*}{$\begin{array}{l}\text { Days of } \\
\text { infection }\end{array}$} & \multicolumn{2}{|c|}{ Spleen } & \multicolumn{2}{|c|}{ Liver } & \multicolumn{2}{|c|}{ Myocardium } & \multicolumn{2}{|c|}{ Skeletal Muscle } \\
\hline & LyFH* & Paras* & Infl. Infilt* & Paras* & Infl. Infilt* $*$ & Paras* & Infl. Infilt $*$ & Paras* \\
\hline $7^{\text {th }}$ & + & -- & -- & -- & -- & -- & -- & -- \\
\hline $9^{\text {th }}$ & $+/++$ & -- & + & -- & + & -- & -- & -- \\
\hline $10^{\text {th }}$ & ++ & -- & $+/++$ & -- & + & -- & + & + \\
\hline $11^{\text {th }}$ & ++ & + & $+/++$ & -- & $+/+++$ & -- & + & + \\
\hline
\end{tabular}

LyFH = Lymphoid follicles hyperplasia; Paras = Parasitism; Infl. Infilt = Inflammatory infiltration; (--) negative; (+) mild degree; (++) moderate degree; +++ intense degree; * from / to

Table 3

Degree of histopathological lesions and parasitism in mice infected with the Colombian strain of T. cruzi by intraperitoneal route

\begin{tabular}{|c|c|c|c|c|c|c|c|c|}
\hline \multirow{2}{*}{$\begin{array}{l}\text { Days of } \\
\text { infection }\end{array}$} & \multicolumn{2}{|c|}{ Spleen } & \multicolumn{2}{|c|}{ Liver } & \multicolumn{2}{|c|}{ Myocardium } & \multicolumn{2}{|c|}{ Skeletal Muscle } \\
\hline & LyFH* & Paras* & Infl. Infilt* & Paras* & Infl. Infilt* & Paras* & Infl. Infilt ${ }^{*}$ & Paras* \\
\hline $14^{\text {th }}$ & + & -- & + & -- & + & -- & + & -- \\
\hline $20^{\text {th }}$ & + & -- & + & -- & $++/+++$ & $++/+++$ & $+/+++$ & $++/+++$ \\
\hline $25^{\text {th }}$ & $+/++$ & -- & $+/++$ & -- & $++/+++$ & $+/++$ & $++/+++$ & + \\
\hline $30^{\text {th }}$ & + & -- & ++ & -- & +++ & $+/++$ & +++ & $+/++$ \\
\hline
\end{tabular}

LyFH = Lymphoid follicles hyperplasia; Paras = Parasitism; Infl. Infilt = Inflammatory infiltration; $(--)$ negative; $(+)$ mild degree; $(++)$ moderate degree; +++ intense degree; * from / to

Table 4

Degree of histopathological lesions and parasitism in mice infected with the Colombian strain of T. cruzi by intragastric route

\begin{tabular}{|c|c|c|c|c|c|c|c|c|}
\hline \multirow{2}{*}{$\begin{array}{l}\text { Days of } \\
\text { infection }\end{array}$} & \multicolumn{2}{|c|}{ Spleen } & \multicolumn{2}{|c|}{ Liver } & \multicolumn{2}{|c|}{ Myocardium } & \multicolumn{2}{|c|}{ Skeletal Muscle } \\
\hline & LyFH* & Paras* & Infl. Infilt* & Paras* & Infl. Infilt* & Paras* & Infl. Infilt* & Paras* \\
\hline $14^{\text {th }}$ & + & -- & + & -- & $+/++$ & + & ++ & + \\
\hline $20^{\text {th }}$ & ++ & -- & ++ & -- & +++ & $++/+++$ & +++ & $++/+++$ \\
\hline $25^{\text {th }}$ & + & -- & ++ & -- & $+/+++$ & $+/+++$ & $+/+++$ & $++/+++$ \\
\hline $30^{\text {th }}$ & + & -- & ++ & -- & +++ & $+/++$ & $+/+++$ & ++ \\
\hline
\end{tabular}

LyFH = Lymphoid follicles hyperplasia; Paras = Parasitism; Infl. Infilt = Inflammatory infiltration; (--) negative; (+) mild degree; (++) moderate degree; +++ intense degree; * from / to 


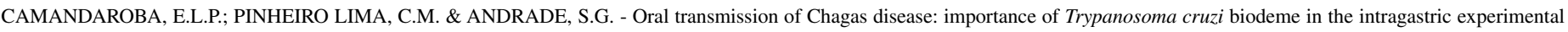
infection. Rev. Inst. Med. trop. S. Paulo, 44(2):97-103, 2002.
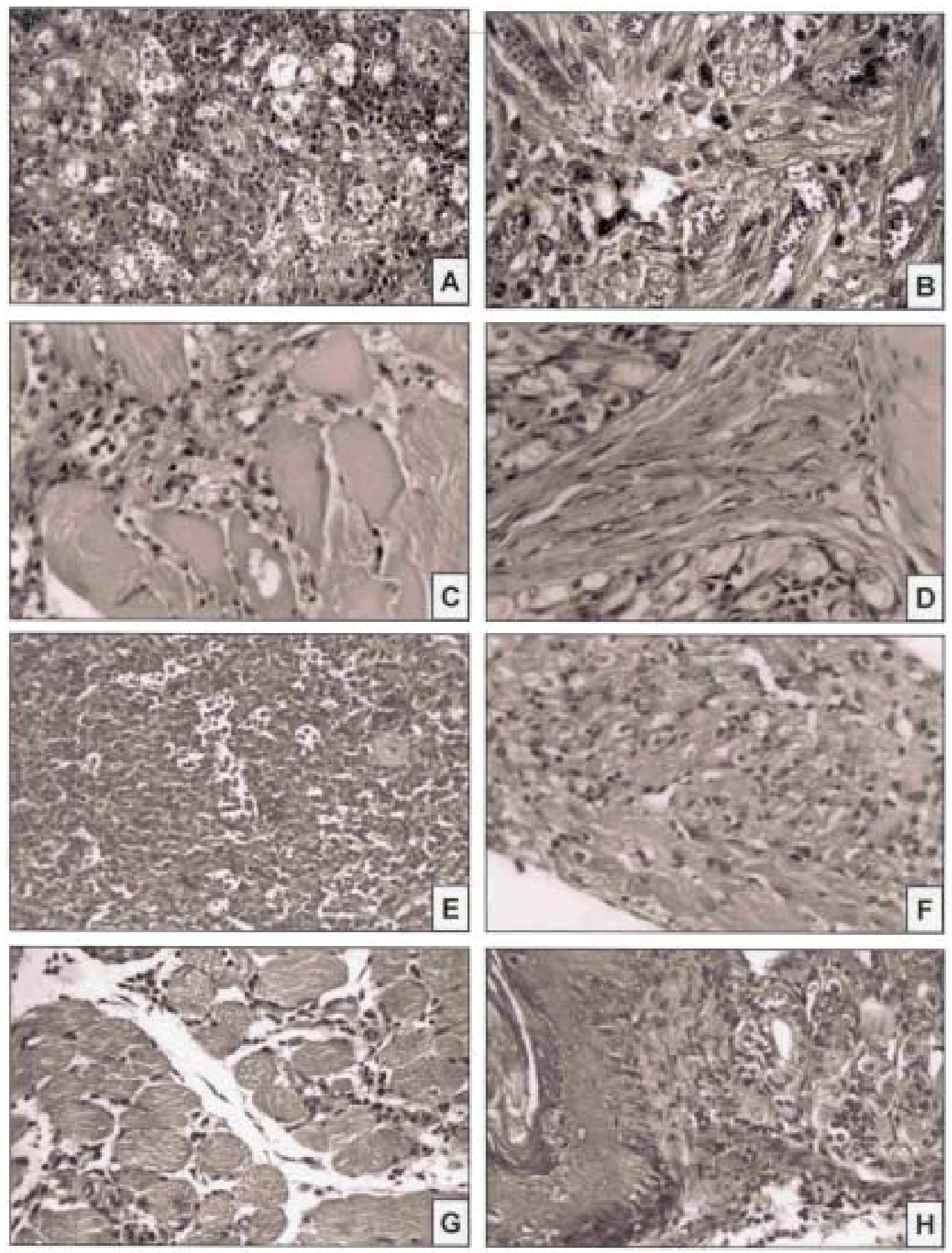

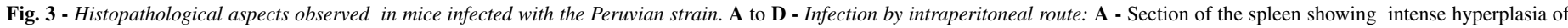

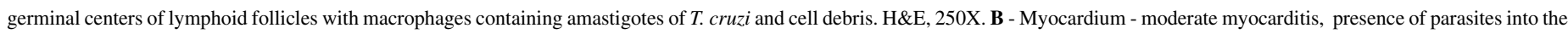

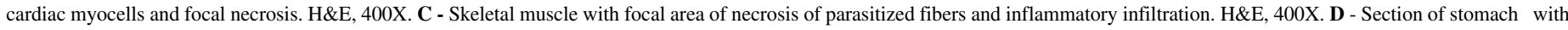

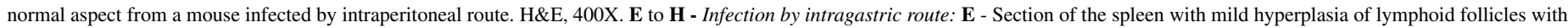

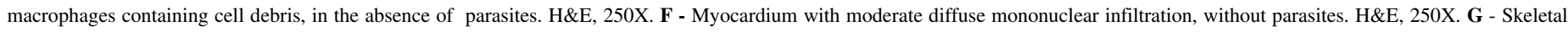

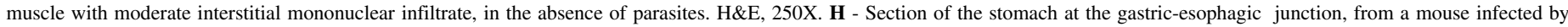
intragastric route; presence of an intense and diffuse mononuclear infiltration of the mucosa and submucosa. H\&E, 400X. 

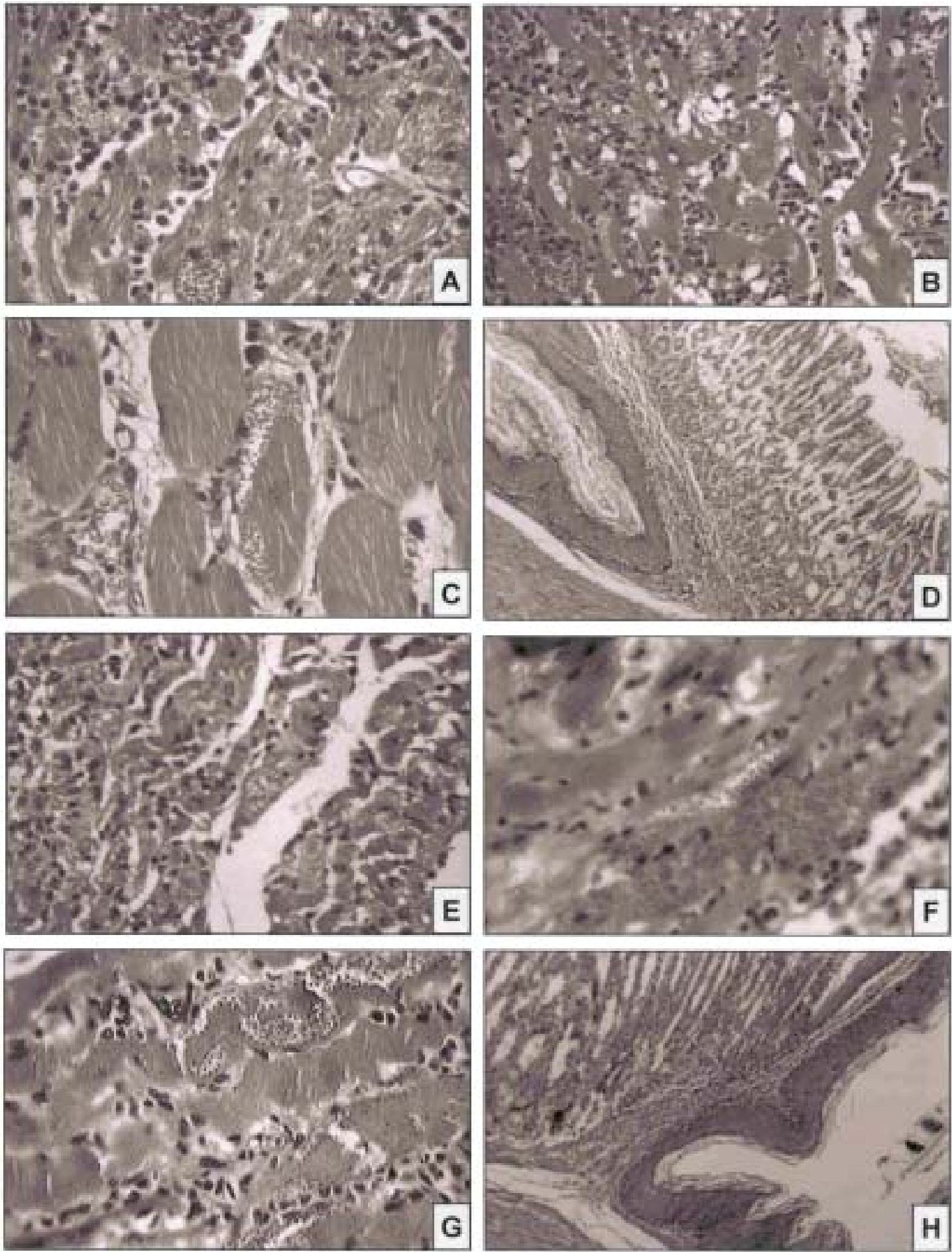

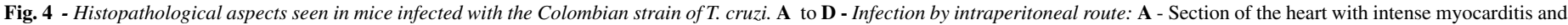

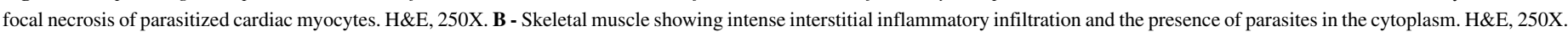

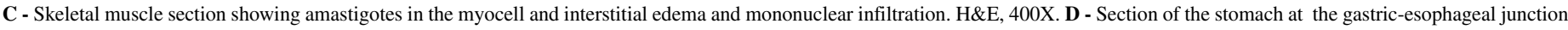

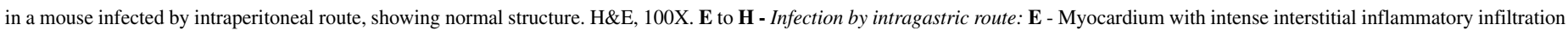

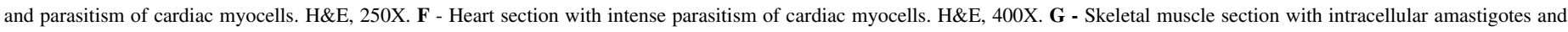

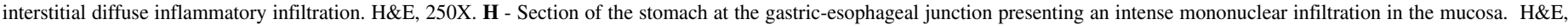
100X. 


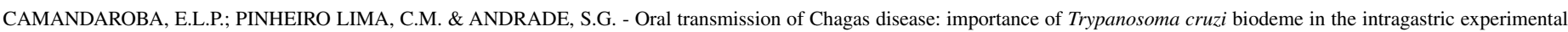
infection. Rev. Inst. Med. trop. S. Paulo, 44(2):97-103, 2002.

in which there are conditions for the contamination of foods or beverages, as referred by SHIKANAI-YASUDA et al. ${ }^{14}$ and VALENTE et $a l^{15}$.

\section{RESUMO}

\section{Transmissão oral da doença de Chagas: importância do biodema do Trypanosoma cruzi na infecção experimental intragástrica}

A ocorrência de microepidemias de infecção pelo Trypanosoma cruzi atribuidas à ingestão de alimentos contaminados com excreta de vetores ou de reservatórios vertebrados, em áreas rurais chamou a atenção para este tipo não vetorial de transmissão da doença de Chagas. Considerando que cepas de diferentes biodemas se distribuem diferentemente nos ciclos silvestre e domiciliar de transmissão, a ocorrência de microepidemias predominantes em áreas próximas aos ecótopos silvestres pode estar relacionada com a cepa do parasito, tendo-se em conta a predominância do Biodema Tipo III, Z1 nestas áreas. No presente estudo foi investigada a infectividade de cepas do $T$. cruzi de diferentes biodemas quando inoculadas por via digestiva. Foi feita inoculação por via intragástrica (VIG) em camundongos Suíços com a cepa Peruana (Biodema Tipo I, Z2b) ou com a Colombiana (Biodema Tipo III, Z1, T. cruzi I). Para controle da infecção, camundongos foram também inoculados por via intraperitoneal (VIP). A cepa Colombiana mostrou alta infectividade e patogenicidade tanto por VIP como por VIG. A cepa Peruana apresentou alta infectividade e patogenicidade pela VIP e mostrou baixa infectividade pela VIG. A mais elevada infectividade pela VIG, da cepa Colombiana, cujo biodema Tipo III, Z1 é o mais freqüentemente encontrado nos hospedeiros silvestres, está de acordo com a ocorrência dos episódios epidêmicos registrados na literatura.

\section{REFERENCES}

1. AMATO NETO, V.; MATSUBARA, L; CAMPOS, R. et al. - Trypanosoma cruzi in the milk of women with chronic Chagas' disease. Rev. Hosp. Clin. Fac. Med. S. Paulo, 47: 10-11, 1992

2. ANDRADE, S.G. - Caracterização de cepas do Trypanosoma cruzi isoladas no Recôncavo Bahiano. Rev. Pat. trop., 3: 65-121, 1974.

3. ANDRADE, S.G. \& MAGALHÃES, J.B. - Biodemes and zymodemes of Trypanosoma cruzi strains: correlations with clinical data and experimental pathology. Rev. Soc. bras. Med. trop., 30: 27-35, 1997.

4. BARRETT, T.V.; HOFF, R.H.; MOTT, K.E. et al. - Epidemiological aspects of three Trypanosoma cruzi zymodemes in Bahia state, Brazil. Trans. roy. Soc. trop. Med. Hyg., 74: 84-90, 1980.

5. CRESCENTE, J. A.; VALENTE, S.A.S.; VALENTE, V.C. \& ARAÚJO, J.A. - Ocorrência de 4 casos agudos de doença de Chagas na vila de Icoarací-PA. Rev. Soc. bras. Med. trop., 25(supl. 1): 29, 1992. (res. 062).
6. DEANE, M.P.; LENZI, H.L. \& JANSEN, A.M. - Trypanosoma cruzi: vertebrate and invertebrate cycles in the same mammal host, the opossum Didelphis marsupialis. Mem. Inst. Oswaldo Cruz, 79: 513-515, 1984

7. HOFT, D.F.; FARRAR, P.L.; KRATZ-OWEN, K. \& SHAFFER, D. - Gastric invasion by Trypanosoma cruzi and induction of protective mucosal immune responses. Infect. Immun., 64: 3800-3810, 1996.

8. MARSDEN, P.D. - Trypanosoma cruzi infections in CFI mice. II. Infections induced by different routes. Ann. trop. Med. Paras., 61: 62-67, 1967.

9. MILES, M.A.; LANHAM, S.M.; SOUZA, A. \& PÓVOA, M. - Further enzymic characters of Trypanosoma cruzi and their evaluation for strain identification. Trans. roy. Soc. trop. Med. Hyg., 74: 221-237, 1980.

10. NERY-GUIMARÃES, F.; SILVA, N. N.; CLAUSELL, D.T. et al. - Um surto epidêmico de doença de Chagas de provável transmissão digestiva, ocorrida em Teutônia (EstrelaRio Grande do Sul). Hospital (Rio de J.), 73: 1767-1804, 1968.

11. NEVES DA SILVA, N.; CLAUSELL, D. T.; NÓLIBOS, H. et al. - Surto epidêmico de doença de Chagas com provável contaminação oral. Rev. Inst. Med. trop. S. Paulo, 10: $265-276,1968$.

12. PINTO, A.Y.N.; HARADA, G.S.; VALENTE, V.C. et al. - Acometimento cardíaco em pacientes com doença de Chagas aguda em microepidemia familiar, em Abaetetuba, na Amazônia Brasileira. Rev. Soc. bras. Med. trop., 34: 413-419, 2001.

13. RECOMMENDATIONS from a Satellite Meeting. International Symposium to commemorate the $90^{\text {th }}$ anniversary of the discovery of Chagas' Disease. Mem. Inst. Oswaldo Cruz, 94 (suppl. 1): 429-432, 1999.

14. SHIKANAI-YASUDA, M.A.; MARCONDES, C.B.; GUEDES, L.A et al. - Possible oral transmission of acute Chagas' disease in Brazil. Rev. Inst. Med. trop. S. Paulo, 33: 351-357, 1991.

15. VALENTE, S.A.S.; VALENTE, V.C. \& FRAIHA NETO, H. - Transmissão da doença de Chagas: como estamos? Considerações sobre a epidemiologia e transmissão da doença de Chagas na Amazônia Brasileira. Rev. Soc. bras. Med. trop. 32(supl. 2):51-55, 1999.

16. VALENTE, V. C.; VALENTE, S.A.S. \& PINTO, A.Y.N. - Perfil parasitológico e sorológico em microepidemia familiar de doença de Chagas em Abaetetuba, Estado do Pará. Rev. Soc. bras. Med. trop., 34: 20-21, 2001a.

17. VALENTE, S.A.S.; PIMENTEL, P.S.; VALENTE, V.C. et al. - Microepidemia familiar de doença de Chagas em Santarém, primeiro registro no oeste do Pará. Rev. Soc. bras. Med. trop., 34 (supl. 1): 19, 2001b.

18. ZINGALES, B.; STOLF, B.S.; SOUTO, R.P.; FERNANDES, O. \& BRIONES, M.R.S. Epidemiology, biochemistry and evolution of Trypanosoma cruzi lineages based on ribosomal RNA sequences. Mem. Inst. Oswaldo Cruz, 94(suppl. 1): 159-164, 1999.

Received: 08 January 2002

Accepted: 10 April 2002 